\title{
Determinants in value appropriation in smallholder farming innovations
}

\author{
Claiton Alorenus Baggio ${ }^{1^{*}}$ () Marcos Roberto Kuhl ${ }^{1}$
}

${ }^{1}$ Universidade Estadual do Centro Oeste (UNICENTRO), Guarapuava, PR, Brasil. E-mail: claiton.baggio@gmail.com. "Corresponding author.

\begin{abstract}
This study aimed to analyze the relationships between the determinants of value appropriation and the innovation strategies in smallholder farming. A survey was conducted with 199 smallholders in the municipality of Guarapuava, in the state of Paraná (PR), Brazil. This quantitative study analyzes data through descriptive statistics and correlation. Results showed that, in general, farmers do not access the determinants of value appropriation through innovation. However, access to government programs aimed commercialization and cooperativism demonstrating a relationship with the determinants of appropriation of value created by innovation. This study contributed to the understanding of mechanisms that allow farmers to obtain better results through innovation strategies.
\end{abstract}

Key words: innovation, complementary assets, smallholder farming.

Análise dos elementos determinantes na apropriação de valor nas inovações da agricultura familiar

RESUMO: Este estudo visa analisar as relações entre os fatores determinantes da apropriação de valor e as estratégias em inovação na agricultura familiar. Para tal, realizou-se uma survey com 199 agricultores familiares do município de Guarapuava, PR. Trata-se de um estudo quantitativo, com análise de dados por meio de estatística descritiva e correlação. Os resultados demonstram que, de maneira geral, os agricultores não acessam os fatores determinantes para a apropriação de valor com a inovação. Porém, o acesso a programas governamentais voltados a comercialização e ao cooperativismo, demonstraram relação com os fatores determinantes para a apropriação do valor criado com a inovação. O trabalho contribui ao buscar a compreensão dos mecanismos que possibilitam o agricultor obter melhores resultados com as suas estratégias em inovações.

Palavras-chave: inovação, ativos complementares, agricultura familiar.

\section{INTRODUCTION}

Most smallholder farming consists of small farmers for whom most of their income comes from their property, where the management and most of the workforce are relatives. Approximately $90 \%$ of the world's farmers are smallholder farmers, and encouraging innovation in this segment is critical to food security and reducing poverty and hunger (FAO, 2014). Smallholder farmers are increasingly valued as having an important role in economic development, promoting local farming arrangements and decentralized development models (LIMA \& WILKINSON, 2002).

Agricultural sector faces a series of challenges, such as a declining price trend for its products and difficulty obtaining satisfactory results (BUAINAIN et al., 2014). According to the United Nations' Food and Agriculture Organization and the Organization for Economic Co-operation and Development (FAO-OECD, 2015), there is a longterm trend of increasing productivity and declining prices of agricultural products, which is likely to persist in Brazil, according to projections. This downward trend threatens the viability of smallholder farmers operating in small areas who cannot compensate price reductions through increased production scale.

In addition to the downward trend in prices, the decline in the farmers' margin is another threat. LIMA and WILKINSON (2002) used the term appropriations to describe the phenomenon 
of progressive reduction in the share of aggregate income by rural properties, which leads to an exclusion of activity. "There is a permanent force in small-scale agriculture that dilutes the positive effects of technological innovation precisely because of the lack of mechanisms to capture value" (SALLES-FILHO \& BIN, 2014, 214). In this way, innovation strategies appropriate for small-scale agriculture are necessary to ensure competitiveness and permanence in rural activity.

Pursuing differentiation and valorization of production are solutions often mentioned as means of improving results through innovation in smallholder farming. According to WAQUIL et al. (2010), low differentiation results in low farmer bargaining power. However, BAGGIO et al. (2016) observed that it is difficult for organic producers to obtain a premium price for their production, even when it is differentiated. Innovations increase productivity; however, this increase results in a price reduction for the producer because of increased supply. Improvements in quality often do not result in better farmer remuneration. Thus, there is no guarantee that an innovation will benefit the farmer, but it will possibly benefit another entity in the supply chain (SALLES-FILHO \& BIN, 2014; MELLO, 2007; PROENÇA et al., 2015). In this way, pursuing innovation strategies so that the farmer obtains better results in appropriating the value created by the innovation becomes important.

When studying the issue of value appropriation with innovation, TEECE (1986) observed that development and adequate access to complementary assets and the apropriability regime are important, that is, the elements that complement and determine the return of the improvements to be made (TEECE, 1986; AFUAH, 2009). Complementary assets are important because they are the mechanism that enables farmers to appropriate the return on the innovation. In their study with small duck breeders in Lima, Peru, SALLES-FILHO and BIN (2014) exemplified the importance of access to complementary assets for achieving gains.

The type of complementary assets and the appropriability regime determined who will appropriate the value created by the innovation, according to TEECE (1986). Complementary assets are all the other resources, besides the innovation itself, that an organization needs to create and capture value from innovation (AFUAH, 2009). The appropriability regime determines the degree of ease or difficulty of imitating an innovation. Europe has succeeded in its policies for smallholder farmers by creating a strong ownership scheme that is, creating protection against imitation of its products. There are currently 4800 geographical indications in Europe, while there are only 22 in Brazil (SALLES-FILHO $\&$ BIN, 2014). These indications allow producers in a specific region legal protection against imitation of their products. This example demonstrated that differentiation by strengthening the appropriability regime and improvement of the commercialization path can be an alternative for valorizing and enabling smallholder farming products. In addition to strengthening the appropriability regime, TEECE (1986) argues that increasing bargaining power and producer margins through access to appropriate complementary assets is also important to achieve good results from innovation. In Brazil, the discussion and the implementation of actions considering these factors are incipient.

TEECE (1986) classifies complementary assets into generic, specialized and co-specialized. Generic assets can easily be contracted through the market and are easily available to all. Specialized and co-specialized assets cannot easily be contracted, which guarantees an advantage to the organizations that own them. Access to specialized and/or co-specialized assets and a strong ownership regime enable the innovator to appropriate most of the value created by innovation. In the case of accessing complementary generic assets and a weak appropriability regime, the value created by innovation is almost totally appropriated by other entities in the supply chain, such as buyers, suppliers and even the final customer (TEECE, 1986).

Thus, it is relevant to analyze how the factors that define the value appropriation from innovation are related to the innovator strategies developed by the farmers and the governmental incentive programs that they access. It is also relevant to analyze whether these strategies allow adequate access to complementary assets and the appropriability regime. According to WINTER (2006), the analysis of innovators' access to complementary assets fills an important gap in the theoretical discussion of appropriation. In addition, the importance of this theme in competitiveness and, consequently, in the continuity in agricultural activity is highlighted.

In this way and within this context, the objective of the present study arises: To analyze the relations between the determinants of value appropriation and innovation strategies for smallholder farmers in Guarapuava, in the state of Paraná (PR), Brazil. In the Guarapuava region, the economy is basically rural, and smallholder farming 
is an important means of livelihood (BASTOS \& FAJARDO, 2014). According to data from the 2006 Census of Agriculture, the Guarapuava region has approximately 296,000 hectares of land occupied by smallholder farming (approximately 20,150 properties/estates), which is the second highest in Paraná (IBGE, 2016).

In addition to the importance of this activity in the city, the study was conducted in Guarapuava, PR, because it has several initiatives aiming for innovation in smallholder farming through governmental programs such as rural extension, farmers' fairs, incentives for new production alternatives and cooperatives and associations with high participation from smallholder farmers. In this way, it is important to analyze whether the initiatives focused on smallholder farming and the farmer strategies help or hinder the appropriation of value from innovation, both for academia and for smallholder farming itself.

\section{MATERIALS AND METHODS}

The study was conducted quantitatively, with data collection performed in November 2016 using a questionnaire (validated by specialists and with a pre-test) with 827 smallholder farmers with DAP, the Declaration of Aptitude to Programa Nacional de Fortalecimento da Agricultura Familiar (PRONAF) in the municipality of Guarapuava, PR, from which 220 responses were obtained. However, after the preliminary analyses, 21 questionnaires were discarded because they showed missing data and/or outliers. The sample is non-probabilistic, and the selection criteria for the target audience were convenience and accessibility. The questionnaire was structured with closed questions measured on a five-point Likert scale ( 1 - totally disagree, 5 - totally agree).

To achieve the objective of the study, farmers' perceptions of innovation performance, the appropriability regime type, the type of access to complementary assets, and perception of participation in government programs aiming commercialization and participation in cooperation were determined. Type of innovation was classified according to the Oslo manual (OSLO, 2005). The appropriability regime is considered strong when there is some barrier or medium that impairs the imitation of innovation. Regime of weak appropriability is characterized when there are no barriers or protections against imitation. Complementary assets are considered generic when they are easily accessible to any innovator without barriers. Specific complementary assets; however, are complementary assets that have barriers and/or limitations to their access and are not readily available to all innovators. The co-specific assets have the same characteristic of the specifics as the barriers and limitations to access but are accessed in the cases studied collectively through cooperatives and associations.

In addition, the internal consistency was determined by means of Cronbach's alpha, where all the indexes were higher than the parameters indicated in the literature (HAIR et al., 2007), that is, above 0.70 .

The constructs are innovation, complementary assets, appropriability regime, participation in programs and cooperation. Among the types of innovation embedded within the construct are innovation in agriculture products, processes and markets (TRIPSAS, 1997; RIBEIRO et al., 2001; LIMA \& WILKINSON, 2002; OECD, 2005; VIEIRA FILHO et al., 2009; AFUAH, 2009; KANG \& AFUAH, 2010; MEURER et al., 2015). Complementary assets considered included considered generic, specific and cospecifics (TEECE, 1986; BURGELMAN \& ROSENBLOOM, 1989; TRIPSAS, 1997; ROTHAERMEL \& HILL, 2005; CECCAGNOLI \& ROTHAERMEL, 2008; FERREIRA et al., 2012; PROENÇA et al., 2015). In the appropriability regime, protection and difficulty of imitating the innovations were considered (TEECE, 1986; WINTER, 2006). Participation in programs and cooperation were considered as indicating farmers' perceptions in relation to the determinants of value appropriation from innovation in participating in government programs aiming marketing, such as producer fairs and marketing of products for the National School Feeding Program and/or participation in cooperatives and associations (RIBEIRO et al., 2001; ROTHAERMEL, 2001; MIELE \& MIRANDA, 2013; SALLES-VIEIRA \& BIN, 2014; LOWITT et al., 2015).

Correlation between the determinants of the value appropriation from innovation and the innovation strategies conducted by farmers through correlation analysis was determined. These construct correlation analyses aim to understand the existing relationships and the intensity of relations between constructs.

\section{RESULTS AND DISCUSSION}

Initially, it is relevant to characterize the sample surveyed in terms of the respondents and the properties. Regarding the respondents, the mean age of the respondents is 42 years, the youngest being 22 years old (three respondents) and the oldest 72 years 
old (two respondents). Only $18 \%$ of the respondents have technical or higher education, while $54 \%$ have only basic education.

Regarding property, it was determined that, on average, 2.7 people work on each property, with only two people for $44 \%$ and three people for $26 \%$ of properties. Only $21 \%$ of the properties surveyed had four or more people working on them, but none have more than five people. The average area of the properties is 26.5 hectares, and for $59 \%$ of the properties, the area is less than 20 hectares. The average gross annual income of $55 \%$ of the properties does not exceed $\mathrm{R} \$ 100,000$, while only $18 \%$ affirmed reaching a gross income above $\mathrm{R} \$ 150,000$. Seventy-six percent of the respondents indicated that they used PRONAF credit, and $70 \%$ indicated that they did not participate in government programs aiming commercialization.

Milk production is conducted in 53\% of the properties, e cultivation of cereals in $48 \%$, cultivation of horticultural crops in $30 \%$, of beef cattle in $17 \%$ and other products (forestry, sheep, honey, eggs, etc.) in only $3 \%$ of cases. It should be noted that $51 \%$ of the properties produce a single item (18\% produce milk and $16 \%$ produce horticultural crops), $39 \%$ produce two products, and the remainder produce three or more products, with only one property producing four products for commercial purposes.

In the cases studied, product innovations consisted of the implementation of new commercial products within the last five years. Innovations in process are considered improvements in the production processes implemented in the last five years. Innovation in the market is considered the implementation of new means and channels of commercialization in the last five years. Innovation was also analyzed through specific questions about the focus of the innovations made and whether they were focused on increasing productivity or on improving product quality. In relation to the actual analyses, the innovation construct presented higher averages in the realization of innovations in process (average 4.52) and in productivity increase (average, 4.43), while innovations in product (average, 3.55), in the market (average, 3.09) and in quality improvement (average, 3.19) obtained lower averages.

The results demonstrate a tendency for farmers to innovate more frequently with a focus on increasing productivity and reducing costs rather than on improving quality, product differentiation and new market strategies. In Brazilian agriculture, the emphasis on technology is mainly on production and processes, since management technology and product development are neglected, especially in the case of smallholder farmers (BATALHA et al., 2007).

There is a consensus among specialists on the subject that value aggregation is necessary to strengthen smallholder farming, which requires the development of trade and unique attributes of this production through innovations (BATALHA et al., 2007). Farmers studied do not generally develop their innovations seeking differentiation and new market strategies. This oversight lowers their bargaining power in pricing and value ownership of their improvements because the definition of the price of production without differentiation regulates supply and demand and the other market players that market it. Improvements in marketing are generally neglected by farmers.

As for the appropriability regime, the average perception of the existence of protection from imitation of the innovation (1.42) and the difficulty for others to imitate production attributes (1.59) was low. These findings demonstrated a perception among farmers that there is no means of protection against imitation of innovations. This perception is likely because most farmers work with technologies, processes and markets without differentiation that are easily accessible to those who want to produce, and there are no major barriers to imitation of innovations. The data agree with the observations by TEECE (1986) that strong appropriability is an exception, not the rule. The results can be explained by the fact that most farmers work with widely diffused technologies and widely available means of commercialization. This ease in imitating the innovation decreases the bargaining power of the farmer, who does not have the means to define, stabilize and value his production, and the price in this case is defined by the supply and demand of the market.

Conversely, results referring to the complementary assets indicate that, in most cases, access to complementary assets occurs through generic assets, without differentiation. The vast majority of producers have the means of distribution and marketing without differentiation, protection or advantage over others. This reduces the power of the producer to add value to their production because there is nothing that differentiates or protects their product. However, access to complementary specialized assets obtained a higher average (3.09), indicating more frequent access than the specialized assets (average, 1.95). Complementary co-specialized assets were generally accessed through cooperatives and associations, which explains their higher frequency.

Specific and co-specific complementary assets were considered to be access to means of 
commercialization and distribution that guaranteed an advantage in the appropriation of innovation value, advantages that were not available to those who did not have such assets. Specific and co-specific complementary assets enabled prices and marketing conditions that would not be possible without access to these assets. These assets generally enable farmers to access better conditions of distribution and commercialization of production. Increasing bargaining power by marketing a larger volume through a cooperative or enabling direct trade to the consumer through trade shows are examples of how complementary co-specific assets improve the marketing conditions of producers. According to FERREIRA et al. (2012), complementary assets must have exclusivity, preference and ownership to increase the likelihood that innovative organizations will be able to appropriate innovation incomes. These positive traits are reported in complementary specialized and co-specialized assets.

The specific and co-specific complementary assets in the cases studied generally guarantee the preference and the possession of the means of commercialization increased the capacity of valorization of the production of the producer. However, exclusivity is a rarely accessed factor, due to lack of differentiation of the production. The cooperative in which most farmers participate brings benefits through access to complementary assets that enable lower prices in the acquisition of inputs, more accessible technical assistance and valuation in marketing due to the greater volume negotiated. These advantages stem from greater ownership and specialization of complementary assets, which increases farmers' bargaining power. However, farmers who access generic complementary assets do not have ownership, exclusivity or preference in marketing, that is, they do not have a competitive advantage in comparison to the others.

The last construct analyzed is the participation in governmental programs aimed commercialization and participation in cooperation, results which indicates that this participation encourages differentiation (average, 3.24), access to supply chains that value production and better results in marketing (average, 3.21). To achieve the sustainable survival of smaller farmers in Brazil, it is necessary to intensify value aggregation capacity, which necessarily demands associative organizations (BATALHA et al., 2007).

Participation in government marketing programs generally occurs through associations and cooperatives. The performance of family farmers in networks increases their bargaining power because they can reach markets that would not be individually accessible, overcome the restrictions of scale and add value to their production (BATALHA et al., 2007). These effects are positive for value-for-innovation by improving access to more attractive supply chains through these programs, as well as improving the bargaining power through increased volume and greater coordination in the supply chain through associations and cooperatives.

Government programs have enabled fairs and more direct marketing to the final customer, which has increased farmers' bargaining power and ability to differentiate and better meet the demands of the end customer. Those who have complementary generic assets do not have the means to coordinate the supply chain, nor to differentiate, to stabilize prices or to value the production, which is usually sold under standardized conditions. Farmers' fairs enable access to complementary, co-specific assets, with which farmers, through association, have the power to set prices, differentiate production and meet customer demands more effectively through contact with the end customer. These benefits increase the potential for valuing and decreasing price swings in marketing.

After the descriptive analysis, the relations between the constructs were determined. The results indicate a significant and positive correlation between the factors studied (Table 1). The appropriability regime showed a positive and significant correlation with innovation. Access to means of protection against imitation is related to innovations' accomplishments. Valuation and protection of innovation imitation in a stronger appropriability regime possibly encourages innovation. A strong appropriability regime makes it possible to differentiate production, which is a promising strategy for smallholder farming as it enables them to offer products to different market niches instead of competing in the global marketplace through cost and price. Developing differentiated products demands innovations in products, processes and the market. This demand possibly explains the relationship between the strongest appropriability regime and the greater frequency in innovations.

The construct of complementary assets presented a positive relation with innovation. This relationship indicates that the more specialized or cospecialized the asset is, the more it tends to influence the increase in the frequency of innovations, which is possibly due to the characteristics of these assets that generate protection, differentiation in relation to others and preference. These advantages can positively influence innovation. Complementary assets must be 
Table 1 - Correlation Coefficient Analysis between the Constructs.

\begin{tabular}{lcccc}
\hline Construct & Innovation & Regime of Appropriability & $\begin{array}{c}\text { Complementary } \\
\text { Assets }\end{array}$ & $\begin{array}{c}\text { Participation in Programs } \\
\text { and Cooperation }\end{array}$ \\
Innovation & 1.000 & $0.364^{* *}$ & $0.437^{* *}$ & $0.421^{* *}$ \\
Regime of Appropriability & $0.364^{* *}$ & 1.000 & $0.520^{* *}$ & $0.335^{* *}$ \\
Complementary Assets & $0.437^{* *}$ & $0.520^{* *}$ & 1.000 & $0.577^{* *}$ \\
Participation in Programs and Cooperation & $0.421^{* *}$ & $0.335^{* *}$ & $0.577^{* *}$ & 1.000 \\
\hline
\end{tabular}

${ }^{* *}$ The correlation is significant at the 0.01 level (two extremities)

created and/or developed to support innovation to gain competitive advantage (RÉVILLION et al., 2004). Innovations are directly linked to complementary assets because these assets determine the outcome of the innovation. The greater development of one's own or shared means of distribution and commercialization through specific complementary assets possibly explains the positive relation of these with a greater frequency in innovation.

Participation in government and cooperation programs has been positively correlated with innovation. Many farmers have innovated because of the opportunity for better results through government marketing programs. BUSSE et al. (2014) observed that public policies are important to breaking down the barriers and enabling the adoption of innovations by farmers in Germany. These programs make it possible to perform activities such as horticulture by making channels more attractive for commercialization, such as fairs organized by the municipality and the National School Feeding Program, for example. Participation in cooperatives, in many cases, enables the production of milk, which also calls for innovations.

Complementary assets present a positive and significant relation with the appropriability regime, indicating that there is a certain tendency for access to more specialized complementary assets for farmers to generate a stronger ownership regime. These results agree with TEECE (1986), who observed that specialized complementary assets guarantee a second line of defense against imitators, being an important source of competitive advantage. Specific complementary assets are a way of strengthening the appropriability regime, even if the product itself is not differentiated (for example, if it is common in agriculture). The increase in the level of appropriability can guarantee competitiveness through pioneering access to complementary assets, mainly image and brand, as well as the cumulativeness in the domain in new supply chains and technologies (RÉVILLION et al., 2004). Specific complementary assets such as brand and differentiated marketing means can ensure that the farmer appropriates a larger share of the value created by his innovation because it increases the possibility of stabilizing the price and valuing production, as well as increases the farmer's bargaining power with the other entities of the supply chain.

\section{CONCLUSION}

The objective of the study was to analyze the relationships between the determinants of the appropriation of value by innovation and the innovation conducted by smallholder farmers. Results showed that the focus of farmer innovation is greater on reducing costs and increasing productivity than on differentiating on new products and markets. In most cases, farmers access generic complementary assets and have a weak appropriation regime, not developing means to differentiate and value their production and marketing or to increase their bargaining power. Production without differentiation in general has its price determined by the supply and demand of the market, presenting volatility and uncertainties in its results. These standardized products without differentiation tend to have their prices devalued over time due to the downward trend in prices of agricultural products.

This devaluation occurs because, in these cases, the farmer does not have the means to appropriate the value of his innovation. This lack of capacity occurs because the technology and means of marketing are widely accessible, and the producer does not have any bargaining power in the commercialization of his production, instead needing to accept the price defined by the offer and demand of the market. This positioning of acting with products and means of commercialization without differentiation is disadvantageous to innovation by 
not remunerating its investment. In particular, the small farmer faces limitations to reducing costs by increasing his production scale.

The devaluation of farmers' production can make smallholder farming unfeasible, and the predominant strategy of seeking competitiveness through increased productivity and cost reduction without jeopardizing the appropriation of value must be rethought. Access to complementary assets in the cases studied is mostly generic; although, co-specialized assets are frequently accessed through cooperativism and associativism, and the differentiation and aggregation of production value is still rarely accomplished. In the vast majority of cases, the regime of appropriability is weak, that is, there is no means of protection from imitations. The cooperative in which most of the farmers studied participate sells the products without differentiation. According to the TEECE model (1986), this positioning is inadequate, and the value created by innovation may possibly be appropriated by other actors in the supply chain.

The participation in government programs aim commercialization and in cooperatives presented positive characteristics for the appropriation of innovation value. This participation enables a better positioning in the supply chain, greater bargaining power in the commercialization and enables the differentiation and protection against the imitation of innovations. That is, it offers greater access to more specific and co-specific complementary assets and access to a stronger ownership regime.

The analyses indicated that there is a significant and positive relationship between the achievement of innovation, a strong appropriability regime, specialized complementary and specialized assets, and participation in government programs aiming commercialization and cooperation. These results agree with literature on the subject and corroborate the importance of the correct positioning of these factors in the appropriation of value through innovation strategies.

This study contributed with information about the importance of correctly positioning the factors, determining the appropriation of the innovation value to obtain better results. Innovating to increase productivity and reduce costs alone may not be enough to guarantee a satisfactory result of innovation. This finding is supported by the evolutionary perspective of innovation and can be corroborated by this study.

Developing a strong appropriation scheme and specialized complementary assets should be issues to consider when deciding to invest in innovations. The whole supply chain and complementary assets should be considered when deciding whether to implement innovation, but technical superiority alone is not enough to guarantee a positive result.

This study indicated that participation in government programs aiming marketing and access to cooperatives contributes in this regard because the farmers increase their bargaining power in marketing, which in turn increases their capacity to value, to define and to stabilize the value of their production through products meaning value and guarantying a greater share of the return of their innovations. In this way, farmers can participate more competitively in the supply chains by reducing brokers, adding value and differentiating their production through processing and industrialization and new production marketing channels. These tactics ensure that most of the value created by the innovations remains with the farmer, a key issue in the outcome for this segment of agriculture. By accessing these items, it is possible to achieve a higher aggregate value of production and lower price variation by avoiding pricing by market supply and demand and to achieve greater ownership of the value created by innovation by achieving greater bargaining power in the production.

\section{DECLARATION OF CONFLICTING INTERESTS}

The present study did not obtain financial resources nor the authors were financed by scholarships, foundations or any other source of resources of third parties for the execution of this study.

\section{REFERENCES}

AFUAH, A. Strategic innovation new game strategies for competitive advantage. New York: Routledge, 2009.

BAGGiO, C.A. et al. Análise do Impacto do Processo de Certificação Orgânica na Inovação e Sustentabilidade na Região Centro-Sul do Paraná. In: Encontro e Gestão de Negócios 2016. Uberlândia. Anais... Uberlândia: Universidade Federal de Uberlândia, CD, 2016.

BASTOS, T.L.; FAJARDO, S. The agrarian context of Guarapuava (Paraná State, Brazil): a reading using the concepts of space and territory. Terr@Plural, v.8, n. 1, p.55-76, 2014. Available from: <https://www.revistas 2.uepg.br/index.php/tp/article/ download/4566/4357>. Accessed: Nov. 29, 2017.

BATALHA, M.O. et al. Tecnologia de gestão e agricultura familiar. In: BATALHA, M.O.; SOUZA FILHO, H.M de. Agricultura familiar e inovação tecnológica no Brasil: características, desafios e obstáculos. Campinas: Editora da Unicamp. p.129-159, 2007.

BUAINAIN, A.M. et al. O mundo rural no Brasil do século 21: a formação de um novo padrão agrário e agrícola. Brasília: Embrapa, 2014. 
BURGELMAN, R.A.; ROSENBLOOM, R.S. Tecnology Strategy: An Evolutionary Process Perspective. Research on Tecnological Innovation, Management, and Policy, v.4, n. 1, p.1-23, 1989 Available from: $<$ http://sjbae.pbworks.com/w/file/ fetch/58749168/ Technology $\% 20$ strategy. $\%$ EC $\% 96 \% 91 \%$ EC $\%$ A7\%84\%EC $\% 84 \%$ 9D.docx $>$. Accessed: Jun. 20, 2016

BUSSE, M. et al. Innovation mechanisms in German precision farming. Precision Agriculture, v.15, n. 4, p.403-426, 2014 Available from: $<$ http://link.springer.com/journal/11119 $>$. Accessed: Jun. 14, 2016. doi: 10.1007/s11119-013-9337-2.

CECCAGNOLI, M.; ROTHAERMEL, F.T. Appropriating the returns from innovation. In: LIBECAP, G.D.; THURSBY, M.C. Technological Innovation: Generating Economic ResultsAdvances in the Study of Entrepreneurship, Innovation and Economic Growth, v. 18, Oxford: Elsevier. 2008. p.11-34. Available from: $<$ https://www.scheller.gatech.edu/directory/faculty/rothaermel/ pubs/CeccagnoliRothaermelReturnstoInnovationFinal.pdf $>$. Accessed: Jun. 10, 2016.

FAO - FOOD AND AGRICULTURE ORGANIZATION OF THE UNITED NATIONS \& OECD - ORGANISATION FOR ECONOMIC COPERATION AND DEVELOPMENT. Agricultural outlook 2015. Paris: OECD Publishing. Available from: $<$ http:// dx.doi.org/10.1787/agr_outlook-2015-en>. Accessed: Feb. 02, 2016.

FAO - FOOD AND AGRICULTURE ORGANIZATION OF THE UNITED NATIONS.The State of Food and Agriculture. Innovation in family farming. Rome: FAO, 2014. Available from: $<$ http://www.fao.org/3/a-i4040e.pdf $>$. Accessed: Mar. 24, 2016.

HAIR JR, J.F. et al. Fundamentos de métodos de pesquisa em administração. Porto Alegre: Bookman, 2007.

FERREIRA, M.P. et al. When the Innovator Fails to Capture Rents From Innovation. Latin American Business Review, v. 13, n. 3, 2012. p.199-217. Available from: <http://www. tandfonline.com/loi/wlab20>. Accessed: Jun. 27, 2016. doi: 10.1080/10978526.2012.730022.

IBGE - INSTITUTO BRASILEIRO DE GEOGRAFIA E ESTATÍSTICA. Censo agropecuário 2006. Available from: $<$ http://www.ibge.gov.br/home/estatistica/economia/agropecuaria/ censoagro/default.shtm>. Accessed: Apr. 20, 2016.

KANG, J.; AFUAH, A. Profiting from innovations: the role of new game strategies in the case of Lipitor of the US pharmaceutical industry. R\&D Management, v. 40, n. 2, 2010. Available from: $<$ https://deepblue.lib.umich.edu/bitstream/handle/2027.42/79168/ j.1467-9310.2010.00597.x.pdf? sequence $=1 \&$ isAllowed $=y>$. Accessed: Jun. 27, 2016. doi: 10.1111/j.1467-9310.2010.00597.x.

LIMA, D.M. de A.; WILKINSON, J. Inovação nas tradições da agricultura familiar. Brasília: CNPQ/Paralelo, 2002. 400p. doi: $0.1007 / \mathrm{s} 10113-015-0805-2$

LOWITT, K. et al. Factors affecting the innovation potential of smallholder farmers in the Caribbean Community. Regional Environmental Change, v. 15, n. 7, p1367-1377, 2015. Available from: <http://link.springer.com/article/10.1007/s10113-015-08052>. Accessed: Jun. 10, 2016.

MELLO, M.T.L.M. Ideias Fundadoras: David Teece: Profiting from technological innovation: Implications for integration, collaboration, licesing and public policy. Revista Brasileira de
Inovação, v. 6, n. 2, p.253-279, 2007. Available from: <http://ocs. ige.unicamp.br/ojs/rbi/article/view/320/237 >. Accessed: Jan. 13, 2016. doi: 10.20396/rbi.v6i2.8648948.

MEURER, A.P.S. et al. Análise da Agroindústria Canavieira nos Estados do Centro-Oeste do Brasil a partir da Matriz de Capacidades Tecnológicas. Rev. Econ. Sociol. Rural, v. 53, n. 1, p.159-178, 2015. Available from: $<$ http://www.scielo.br/scielo.php?script=sci arttext\&pid=S0103-20032015000100159>. Accessed: May 19, 2016. 10.1590/1234-56781806-9479005301009.

MIELE, M.; MIRANDA, C. O desenvolvimento da agroindústria brasileira de carnes e as opções estratégicas dos pequenos produtores de suínos do Oeste Catarinense no início do século 21. In: CENTRO DE GESTÃO E ESTUDOS ESTRATÉGICOS (CGEE). A pequena produção rural $\mathbf{e}$ as tendências do desenvolvimento agrário brasileiro: ganhar tempo é possível? Brasília: CGEE, 2013. p.201-233.

OECD - ORGANISATION FOR ECONOMIC CO-OPERATION AND DEVELOPMENT. Manual de Oslo: diretrizes para coleta e interpretação de dados sobre inovação. 3 ed. Trad. FINEP. Rio de Janeiro: OECD; Eurostat; FINEP, 2005. Available from: <http:// www.oei.es/salactsi/oslo2.pdf $>$. Accessed: Sep. 10, 2015.

PROENÇA, A. et al. Gestão da inovação e competitividade no Brasil: da teoria à prática. Porto Alegre: Bookman, 2015.

RÉVILLION, J.P.P. et al. Estudo do Processo de Inovação Tecnológica no Setor Agroindustrial - Estudos de Caso na Cadeia Produtiva de Leite Fluido no Sistema Setorial de Inovação da França. Revista de Administração Contemporânea, v. 8, n. 3, 2004, p.75-98. Available from: <http://www.scielo.br/pdf/rac/ v8n3/v8n3a05.pdf $>$. Accessed: Mar. 10, 2016. doi: 10.1590/ S1415-65552004000300005.

RIBEIRO, M.T.F. et al. A Construção de estratégias competitivas explorando diferentes abordagens dinâmicas. Organ. Soc., v. 8, n. 20, p.1-19, 2001. Available from: <http://www.scielo.br/scielo. php?script $=$ sci_arttext\&pid=S1984-92302001000100002\&lng $=$ en $\&$ nrm $=$ iso $>$. Accessed: Jun. 23, 2016. doi: 10.1590/S198492302001000100002

ROTHAERMEL, F.T. Incumbent's advantage through exploiting complementary assets via interfirm cooperation. Strategic Management Journal, v. 22, n. 6-7, p.687-699, 2001. Available from: $<$ https://www.scheller.gatech.edu/directory/faculty/rothaermel/pubs/ 01SMJ.pdf $>$. Accessed: Jun. 20, 2016. doi: 10.1002/smj.180.

ROTHAERMEL, F.T.; HILL, C.W.L. Technological Discontinuities and Complementary Assets: A Longitudinal Study of Industry and Firm Performance. Organization Science, v. 16, n. 1, p.52-70, 2005. Available from: <http://search.proquest. com/docview/213832512/fulltextPDF/58FAE9C2E0DB4D83P $\mathrm{Q} / 2$ ?accountid $=42153>$. Accessed: Jun. 16, 2016. doi: 10.1287/ orsc. 1040.0100 .

SALLES-FILHO, S.; BIN, A. Reflexões sobre os rumos da pesquisa agrícola. In: BUAINAIN, A.M. et al. O mundo rural no Brasil do século 21: a formação de um novo padrão agrário e agrícola. Brasília: Embrapa, 2014. p.423-453.

TEECE, D.J. Profiting from technological innovation: Implications for integration, collaboration, licensing and public policy. Research Policy, v. 15 , n. 6, p.285-305, 1986. Available from: <https:// bdpems.wiwi.hu-berlin.de/portal/sites/default/files/Teece $\% 20 \%$ 
20public\%20policy\%20(upload)\%20.pdf>. Accessed: Mar. 13, 2016. doi: 10.1016/0048-7333(86)90027-2.

TRIPSAS, M. Unraveling the process of creative destruction: complementary assets and incumbent survival in the typesetter industry. Strategic Management Journal, v. 18, p.119, 1997. Available from: <http://search.proquest.com/docview/231174671/ pageview PDF/ 5 D 4 CDFA 3 DB 14 A C 9PQ/ 11 ? account $\mathrm{id}=42153>$. Accessed: Jun. 16, 2016. doi: 10.1002/(SICI)10970266(199707)18:1+<119::AID-SMJ921>3.3.CO;2-S.

VIEIRA FILHO, J.E.R. et al. Abordagem Alternativa do Crescimento Agrícola: um Modelo de Dinâmica Evolucionária. Revista Brasileira de Inovação, v. 4, n. 2, p.425-476, 2009.
Available from: <http://ocs.ige.unicamp.br/ojs/rbi/article/ view/293>. Accessed: Mar. 29, 2016. doi: 10.1590/S010320032012000400008

WAQUIL, P.D. et al. Mercado e comercialização de produtos agrícolas. Porto Alegre: Ed. da UFRGS, 2010. Available from: $<$ http://www.ufrgs.br/cursopgdr/downloadsSerie/derad020.pdf $>$. Accessed: Mar. 13, 2016.

WINTER, S.G. The logic of appropriability: From Schumpeter to Arrow to Teece. Research Policy, v. 35, n. 8. 2006. Available from: <https://www.econstor.eu/bitstream/10419/89518/1/ 518481115.pdf $>$. Accessed: Jun. 11, 2016. doi: 10.1016/j. respol.2006.09.009. 